\title{
Population differentiation of eelpout Zoarces viviparus in a Danish fjord
}

\author{
Rikke Bjerring Olsen ${ }^{1,2}$, Katherine Richardson ${ }^{1, *}$, Vibeke Simonsen ${ }^{2}$ \\ ${ }^{1}$ University of Aarhus, Department of Marine Ecology, Finlandsgade 14, 8200 Århus N, Denmark \\ ${ }^{2}$ National Environmental Research Institute, Vejlsoevej 25, 8600 Silkeborg, Denmark
}

\begin{abstract}
Studies carried out in the early and mid-1900s demonstrated the presence of 2 separate populations of eelpout Zoarces viviparus associated with the outer and inner parts, respectively, of Mariager Fjord in eastern Jutland, Denmark. In 1997, the fjord experienced a major fish kill resulting from a hypoxia/anoxia event. The purpose of this study was to examine whether 2 populations could still be identified in this fjord in 1998. The same morphological traits and genetic methods used in the earlier studies were employed for the present study. Neither the morphological characteristics nor any of the 7 investigated allozymes examined revealed any population differentiation between fish caught in the inner and outer fjord in 1998. It was concluded that there was no population differentiation in eelpout in this fjord in 1998. In addition, growth rates (estimated from otolith growth zones) appeared to be the same in fish caught in the inner and outer fjord in 1998. Estimated growth rates for fish in autumn/winter 1997 to spring/summer 1998 (assumed to be the growth season for the year of the hypoxia event) were lower than those estimated for autumn/winter 1996 to spring/summer 1997. Genetic data obtained in studies from the 1970s were re-examined and the earlier conclusion regarding the existence of 2 populations was confirmed to be robust. Thus, a change in population distributions of eelpout may have occurred in this fjord between the 1970s and the late 1990s. As the characteristics of the fish found throughout the fjord in 1998 resembled those of the 'outer fjord' population identified in earlier studies, it is argued that the inner fjord population identified in earlier studies has been reduced or eliminated and that the outer fjord population has moved into the inner fjord. A comparison of catch statistics from the 1970s and 1998 suggests a major decrease in stock size during this same period.
\end{abstract}

KEY WORDS: Zoarces viviparus $\cdot$ Meristic traits $\cdot$ Isozymes $\cdot$ Growth $\cdot$ Population differentiation

\section{INTRODUCTION}

Population differentiation of eelpout Zoraces viviparus (L.) in Mariager Fjord, Denmark, was first identified by Schmidt $(1917 \mathrm{a}, \mathrm{b})$. In fish from samplings made in 1915 and 1916, he examined the variation in 4 morphological characteristics: numbers of vertebrae, pectoral fin rays, dorsal fin hard rays and pigment spots on the dorsal fin. On the basis of the patterns in distribution of these morphological characteristics, he concluded the presence of 2 'races' or populations of eel-

*Corresponding author. E-mail: richardson@biology.au.dk pout: 1 in the inner and 1 in the outer part of Mariager Fjord.

The development of electrophoretic methodology to examine the genetic composition of wild populations late in the last century gave researchers the opportunity to return to the question of population differentiation for this fish in Mariager Fjord. In the 1970s and 1980 s, a number of studies examining the population structure of eelpout in this fjord were carried out (Christiansen \& Frydenberg 1974, Christiansen et al. 1976, 1981, 1984, 1988). All of these investigations demonstrated a tendency for population differentiation of eelpout in Mariager Fjord. For the most comprehensive of these studies (Christiansen et al. 1981, 1988), a 
sampling program was carried out in 1977, where sampling sites were located as closely as possible to the sites visited by Schmidt $(1917 \mathrm{a}, \mathrm{b})$. Christiansen et al. $(1981,1988)$ examined both morphological traits and allozymes of the fish.

The tendency in morphological characteristics found by Schmidt in 1915 and 1916 (Schmidt 1917a,b) was again found in 1977, although some of the average numbers had changed slightly (Christiansen et al. 1981, 1988). All 4 characteristics showed significant differences between sites. Of the 7 investigated loci, 1 (ESTIII) also varied significantly throughout the fjord. The allelic frequencies of ESTIII and the means of the morphological characteristics were most alike at the 3 innermost stations and at the 2 outer stations. This indicated that the Mariager Fjord population of eelpout was comprised of 2 distinct groups (Christiansen et al. 1981, 1988). The observed means of the morphological traits and allelic frequencies were not linearly correlated with the distance between sites but showed significant differences between populations located down to $5 \mathrm{~km}$ apart. This observation led the authors to exclude migration as a possible causative agent for the observed differences. Furthermore, selection caused by spatial variation in the physical environment of the fjord was rejected due to the short distance between the highly differentiated populations (Christiansen et al. 1981). Thus, the authors concluded that no unambiguous explanation could be given for the observed differentiation.

Mariager Fjord (Fig. 1) is located on the eastern coast of Jutland in Denmark. It is a typical threshold fjord (42 $\mathrm{km}$ in length) with water depths up to $30 \mathrm{~m}$ in the inner region. The outer region of the fjord is shallow (0 to 2 $\mathrm{m}$ ) and salinity is 20 to $25 \%$. In the deeper inner fjord, salinity ranges from 12 to $17 \%$ in the upper $10 \mathrm{~m}$ of the water column and 18 to $24 \%$ at the mouth of the fjord.
Throughout the year temperatures reach $20^{\circ} \mathrm{C}$ in the surface water layer, whereas temperatures in the deep part are between 2 to $6^{\circ} \mathrm{C}$. The fjord has experienced eutrophication in recent decades and a major fish kill was recorded in August/September 1997 as the result of a hypoxia/anoxia event all over the fjord. During this event, oxygen saturation levels as low as 0 to $2 \%$ were recorded in the inner part of the fjord (Andersen et al. 1998). Eelpout were among the fish involved in the kill.

In 1998 (i.e. the year following the fish kill) we collected eelpout in Mariager Fjord with the purpose of examining their population structure. Our objective was to compare population characteristics and structure found in 1998 with those determined in the early and mid-1900s. Therefore, we chose to employ exactly the same methods as those used in the earlier studies rather than the more modern analytical methods now available for identifying genetic characteristics of a population.

\section{MATERIALS AND METHODS}

Eelpout were collected in August/October 1998 from 5 stations in Mariager Fjord, ranging from the inner part to the mouth of the fjord. The fishing was carried out using traps placed at 1 to $2 \mathrm{~m}$ depth. The samples from each station and the number of fish caught are presented in Table 1 along with data from 1977 (Christiansen et al. 1981, 1988). To facilitate comparison of samples between years, we have renamed the samples using the year and the area code, e.g. 98-1, where 98 indicates the year of sampling (1998) and 1 the area closest to the end of the fjord (see Fig. 1). Live fish were returned to the lab for examination, where tissue samples (brain, heart and liver) were removed for electrophoretic analysis, avoiding damage to the morphological characteristics.

Table 1. Zoarces viviparus, List of eelpout collected in Mariager Fjord in 1998 and 1977

\begin{tabular}{|c|c|c|c|c|c|c|}
\hline Year & Sample abbreviation & Month & No. of fish & Morphological traits & Isozymes/proteins $^{a}$ & Ecological traits \\
\hline 1998 & $\begin{array}{c}98-2 \\
98-3 \\
98-4 \\
98-4 / 5^{b} \\
98-5\end{array}$ & $\begin{array}{l}\text { Aug } \\
\text { Aug } \\
\text { Aug } \\
\text { Sep } \\
\text { Sep }\end{array}$ & $\begin{array}{r}44 \\
18 \\
65 \\
104 \\
17\end{array}$ & $\begin{array}{l}\text { Dorsal hard rays } \\
\text { (D), pectoral fin } \\
\text { rays (PR), } \\
\text { pigment spots } \\
\text { (PS), vertebrae (V) }\end{array}$ & $\begin{array}{c}\text { AAT, } \\
\text { ADA, EST, } \\
\text { MDHP, } \\
\text { PGM, } \\
\text { TPI }\end{array}$ & $\begin{array}{c}\text { Age, } \\
\text { length, sex, } \\
\text { weight }\end{array}$ \\
\hline 1977 & $\begin{array}{l}77-1 \\
77-2 \\
77-3 \\
77-4 \\
77-5\end{array}$ & $\begin{array}{l}\text { May } \\
\text { Apr } \\
\text { Apr } \\
\text { Apr } \\
\text { Mar }\end{array}$ & $\begin{array}{l}240 \\
300 \\
300 \\
300 \\
270\end{array}$ & $\begin{array}{l}\text { Dorsal hard rays } \\
\text { (D), pectoral fin } \\
\text { rays (PR), } \\
\text { pigment spots } \\
\text { (PS), vertebrae (V) }\end{array}$ & $\begin{array}{c}\text { AAT, } \\
\text { ADA, EST, } \\
\text { MDHP, } \\
\text { PGM, } \\
\text { HB }^{\mathrm{c}}\end{array}$ & $\begin{array}{c}\text { Age, } \\
\text { length, sex, }\end{array}$ \\
\hline
\end{tabular}



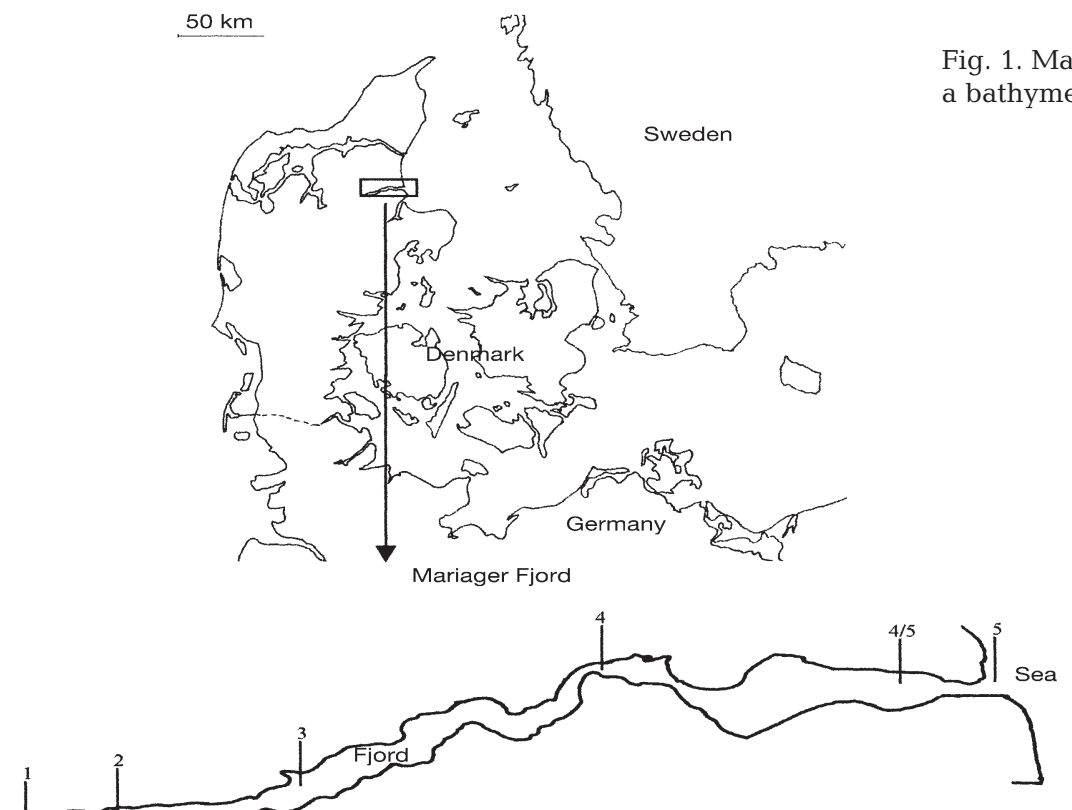

Depth profile of Mariager Fjord

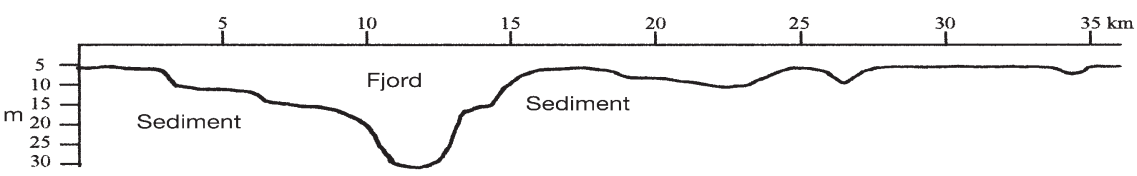

Tissue samples and fish were stored at -80 and $-20^{\circ} \mathrm{C}$, respectively, until further analysis.

Morphological analysis. Four meristic traits were studied: the number of right pectoral fin rays (PR), the number of pigment spots on the dorsal fin (PS), the number of hard rays in the dorsal fin (D) and the number of vertebrae (V). The 3 first mentioned traits were counted according to Schmidt $(1917 \mathrm{a}, \mathrm{b})$, using a forehead lens with $2 \times$ magnification. The vertebrae were counted from X-ray film. The film used was ULTRA VISION G, $24.0 \times 30.0$ medical X-ray film (Sterling Diagnostics Imaging, Breward, NC) exposed for $25 \mathrm{~s}$ at $10 \mathrm{~mA}$ and $25 \mathrm{kV}$. Fish whose traits were difficult to count were excluded from the analysis.

Isozyme analysis. The tissue samples (brain, heart and liver) were analysed for 6 enzymes including the 5 previously studied in 1977. The method used was horizontal starch gel electrophoresis. The enzymes were adenosine deaminase (ADA) (Simonsen \& Christiansen 1981), aspartic acid aminotransferase (AAT) (Simonsen \& Christiansen 1984), esterase (EST) (Simonsen \& Frydenberg 1972), malic enzyme (MDHP) (Frydenberg \& Simonsen 1973), phosphoglucomutase (PGM) (Hjorth 1971) and triosephosphate isomerase (TPI). TPI was revealed in the liver, the buffer used was a histidinecitrate buffer $\mathrm{pH}=7.0$ (also used for ADA, EST and PGM), and the staining procedure for TPI followed Manchenko (1994).
Fig. 1. Maps of Denmark, Mariager Fjord and a bathymetric transect of the fjord
The abbreviations of the enzymes are as indicated above. When written in italics these indicate the loci corresponding to the enzyme, which are numbered with Roman numerals according to the migration towards the anode, i.e. the most anodic migrating zone was 'I' etc.

Ecological analysis. Total length to the nearest $0.5 \mathrm{~cm}$ and wet weight $(\mathrm{g})$ were recorded for all fish. Sex was determined along with the reproductive stage of the females. Age was determined from sagittae otoliths (Svedäng et al. 1997), and was designated as ' $1+$ ', ' $2+$ ', ' $3+$ ', etc. for all fish between 1 and $2 \mathrm{yr}, 2$ and 3 yr etc.

The width of saggitae growth zones was used for estimation of relative growth. After polishing the otoliths on the sulcus side, growth zones were measured from the centre and vertically down from the length axis on the right otolith. The width $(\mu \mathrm{m})$ of the opaque and hyaline zones was estimated from a microscope $(50 \times)$ connected to a PC using the software Olylite, Version 2.20. Due to difficulty in distinguishing the outermost opaque and hyaline zones, these were classified as 1 zone. When comparing age-specific growth between year classes $2+$ and 3+, it was, therefore, necessary to combine opaque and hyaline zones for inner rings in the older year classes in order to compare them with the outermost rings in a younger year class. The growth period, including the hypoxia event might be 
reflected in the growth of the otolith in autumn/winter 1997. According to Svedäng et al. (1997), the formation of the hyaline winter ring in eelpout from southern Sweden was initiated in August.

Statistical analysis. Morphological data: Assuming the morphological data to be approximately normally distributed (Schmidt 1921), 1-way ANOVA (Sokal \& Rohlf 1995) was performed, with Levene's test of variance homogeneity (SAS Version 8.1), and Welch's ANOVA if variance heterogeneity occurred (SAS version 8.1), in order to test for differences in traits among stations. A posteriori multiple comparisons between samples were conducted by Tukey-Kramer comparison (Sokal \& Rohlf 1995). One-way ANOVA and $t$-tests were conducted on pooled samples divided into sex and age. Power analyses for the unequal sample sizes were estimated according to Zar (1996).

Isozyme data: The program G-stat, Version 3.1 (genetical statistical programs for the analysis of population data - available from: H. R. Siegismund, hanss@bot.ku.dk) was applied for estimation of allelic frequencies and deviations from Hardy-Weinberg (maximum likelihood estimates, G). Williams' correction was used for all G-tests. Wright's F-statistics were estimated by the programme FSTAT 1.2 (according to Weir \& Cockerham 1984, Goudet 1995) using 1000 permutations. Tests for linkage disequilibrium between loci, pair-wise comparison between allelic frequencies and tests for homogeneity of allelic frequencies between samples were carried out using Fisher's exact test, with 1000 iterations, using the program package GENEPOP Version 3.1 (Raymond \& Rousset 1995). Sequential Bonferroni corrections (Rice 1989) were used to correct for multiple use of the same individuals. Isolation by distance was tested by applying a Mantel test using the program ISOLDE in the package of programs GENEPOP (Raymond \& Rousset 1995). Data from 1977 on 5 loci (Christiansen et al. 1988) and data for the locus MDHPI, provided by F. B. Christiansen \& V. Simonsen, were analysed along with the data from 1998.

Ecological data: Even sex distribution was tested by applying $\chi^{2}$-test with Yates' correction for continuity
(Fowler et al. 1998) in each sample from the investigations in 1915, 1977 and 1998. Homogeneity of length and of weight between sexes (pooled samples) was tested by a paired $t$-test (Sokal \& Rohlf 1995). The difference in mean age between samples was tested by 1 way ANOVA, and so was homogeneity of lengths of the most frequent age class, stratified by sex. When homogeneity of variance was not accepted (Levene's test of variance homogeneity), Welsh's ANOVA was conducted. Tukey-Kramer multiple comparisons between samples (Sokal \& Rohlf 1995) were used and a posteriori ANOVA conducted, if significant differences were observed. Differences in the length-weight (lntransformed) relationships between sexes were tested by analysis of co-variance in each sample (Sokal \& Rohlf 1995). Condition factor (CF) was calculated for each individual as weight/length ${ }^{3}$ (King 1995) and tested against sex by a $t$-test. One-way ANOVA was used to test for equal CF (divided by sex) between samples. Testing overall correlation between length and CF was done by Pearson correlation (Fowler et al. 1998).

Difference in growth zones among males and females at each station were tested with a $t$-test whereas difference in growth zones of 2+ individuals between stations was tested with 1-way ANOVA. Testing growth zones between year classes 2+ and 3+ was done by $t$-test.

Catch data from 1969, 1974 and 1977 were obtained from logbooks from RV 'Genetica I'. Unpublished length and age data from the same years were provided by F. B. Christiansen \& V. Simonsen, University of Aarhus. Mean catch per unit effort (CPUE) from the 3 earlier investigation years was calculated for the inner and the outer region of the fjord, as was CPUE from 1998. CPUE was calculated as the number of eelpout caught per trap per $24 \mathrm{~h}$ fishing period.

\section{RESULTS}

\section{Morphological analysis}

Table 2. Zoarces viviparus. Means and standard deviations (SD) of meristic characters in eelpout collected in 1998 at 5 stations in Mariager Fjord. See Table 1 for abbreviations

\begin{tabular}{|c|c|c|c|c|c|c|c|c|c|c|c|c|}
\hline \multirow{2}{*}{$\begin{array}{l}\text { Trait } \\
\text { Sample }\end{array}$} & \multicolumn{3}{|c|}{${ }_{-} \mathrm{PR}$} & \multicolumn{3}{|c|}{ PS } & \multicolumn{3}{|c|}{$\longrightarrow \mathrm{D}$} & \multicolumn{3}{|c|}{$\mathrm{V}$} \\
\hline & $\mathrm{N}$ & Mean & SD & $\mathrm{N}$ & Mean & $\mathrm{SD}$ & $\mathrm{N}$ & Mean & SD & $\mathrm{N}$ & Mean & SD \\
\hline $98-2$ & 44 & 18.6 & 0.6 & 44 & 13.0 & 1.8 & 44 & 7.5 & 1.4 & 38 & 113.2 & 2.5 \\
\hline $98-3$ & 18 & 18.7 & 0.5 & 18 & 14.1 & 1.5 & 17 & 7.6 & 1.3 & 17 & 114.1 & 2.2 \\
\hline $98-4$ & 64 & 18.6 & 0.8 & 64 & 12.8 & 2.2 & 67 & 7.6 & 1.4 & 58 & 113.2 & 2.8 \\
\hline $98-4 / 5$ & 104 & 18.6 & 0.7 & 104 & 13.2 & 2.3 & 101 & 7.7 & 1.4 & 91 & 114.1 & 2.8 \\
\hline $98-5$ & 17 & 18.3 & 1.0 & 17 & 12.9 & 2.5 & 17 & 7.6 & 1.2 & 15 & 114.9 & 2.2 \\
\hline
\end{tabular}

No significant differences between samples collected in 1998 were observed for any of the 4 morphological traits (PR: $F_{4,242}=1.09, \mathrm{p}=0.36$, power $=0.07$; PS: $F_{4,242}=1.43, \mathrm{p}=0.22$, power $=0.15$; $\mathrm{D}: F_{4,241}=0.08, \mathrm{p}=0.99$, power $=0.05$; $\mathrm{V}: F_{4,214}=2.22, \mathrm{p}=0.07$, power $=0.38$ under the assumption that no effect of sex and age was present (see Table 2). However, when testing for age effect (pooled samples) 1 yr olds appeared to have significantly larger values 
of $\mathrm{V}$ and lower values of $\mathrm{PR}$ than 2 and $3 \mathrm{yr}$ olds $\left(F_{2,207}=4.61, \mathrm{p}=0.01\right.$, power $=0.66$; and $F_{2,232}=3.04$, $\mathrm{p}=0.05$, power $=0.41$ respectively). No effect of sex was observed in pooled samples for any of the traits (PR, PS, D and $\mathrm{V}<0.05)$.

The traits (PR, PS, D and V) were compared to the same traits studied in 1915 (Schmidt 1917a,b) and 1977 (Christiansen et al. 1988). Fig. 2 shows the means of these 4 traits for the 3 periods of sampling. In the samples from 1915 and 1977, the mean of PR showed a decline when moving from the end of the fjord to the mouth. In contrast, the means of the samples from 1998 were nearly the same. The results for PS and D did not show such convincing differences throughout the fjord. However, V increased in number throughout the fjord in 1915 and 1977, while again, means of the numbers of V were similar through the fjord in 1998 (Fig. 2). In the cases of both the number of fin rays in the right pectoral fin and the number of vertebrae, the eelpout caught in Mariager Fjord in 1998 resembled most closely the fish caught in the outer fjord in the earlier studies.

\section{Isozyme analysis}

The loci studied in the 1998 samples were AATIII (former GOTIII), ADA, ESTIII, MDHPI, MDHPII, PGMI, $P G M I I$ and TPI. Compared to the previous samples analysed for isozymes, MDHPII and TPI were new loci, which were possible to score. The allelic frequencies and tests for fitted Hardy-Weinberg proportions are presented in Table 3. Due to the small sample sizes in 1998, the sex of the fish was ignored.

Forty tests for fit to Hardy-Weinberg expectations were performed, and 4 of these showed significant deviations, which was about twice the number of deviations expected, but no tendency was found in the data. The same observation was found for the samples from 1977. Linkage disequilibrium among loci within a station in 1977 was found for 4 out of 105 tests performed and, in 1998, 6 combinations out of 140 revealed linkage disequilibrium. No linkage disequilibrium across all populations in the fjord was found for any of the loci pair-wise combination, neither in 1998 nor in 1977 (Fisher's exact test, all p > 0.05).

When testing for homogeneity across all populations, the samples from 1998 showed homogeneity among the samples in the fjord $\left(\chi^{2}=25.79, \mathrm{df}=16, \mathrm{p}=0.06\right)$. The samples from 1977 revealed significant deviation from homogeneity $\left(\chi^{2}=\infty\right.$, df $\left.=14, p<0.01\right)$. When doing pair-wise comparison of allelic distribution among the stations, 2 of 80 tests revealed significance. One was found for the enzyme ADA (Sample 98-2 vs 98-4/5, Fisher's exact test, $\mathrm{p}=0.002$ ) and one for
MDHPII (Sample 98-3 vs 98-4, p = 0.002). Similar comparisons of the fish collected in 1977 revealed significance for 5 of 70 tests, and all found for the enzyme EST (Sample 77-1 vs 77-5, p < 0.002; Sample 77-2 vs $77-4$ or $77-5, \mathrm{p}<0.001$; Sample $77-3$ vs $77-4$ or $77-5$, $\mathrm{p}<0.001)$. The homogeneity among the samples was further supported by $F_{\mathrm{ST}}$ being not significantly different from zero for the samples from 1998 ( $p=0.096)$. The heterogeneity among the samples from 1977 was obvious as $F_{\text {ST }}$ deviated significantly from zero ( $\mathrm{p}=$ 0.001). A pair-wise comparison of the geographic distance and the estimated values for $F_{\mathrm{ST}}$ did not reveal correlation between these 2 parameters (Spearman rank correlation, $\mathrm{p}=0.16$ for 1998 and 0.10 for 1977).
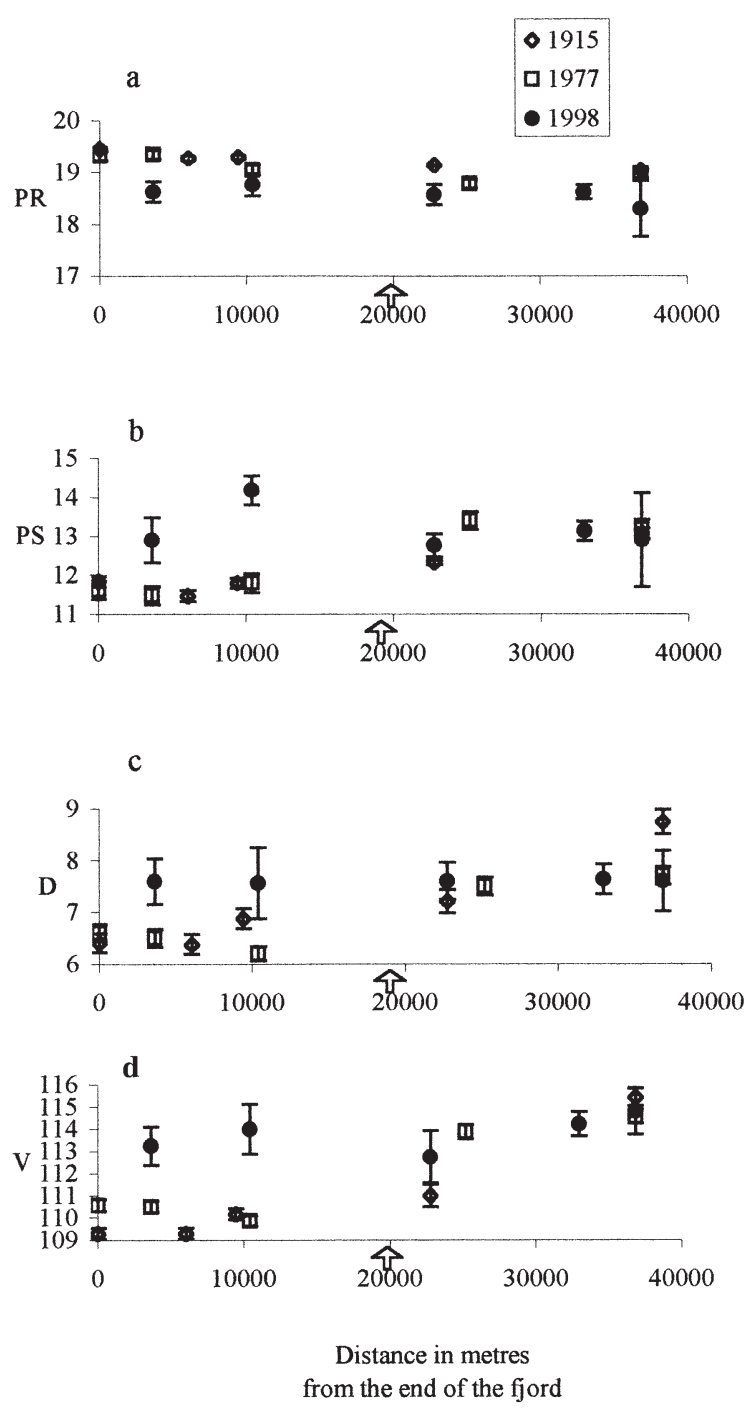

Fig. 2. Zoarces viviparus. Means of 4 meristic traits of eelpout from Mariager Fjord 1915, 1977 and 1998. (a) Fin rays in the right pectoral fin (PR), (b) pigment spots (PS), (c) hard fin rays in the dorsal fin (D), and (d) vertebrae (V). The arrow indicates the borderline between the deeper inner fjord and the shallower outer fjord 
Table 3. Zoarces viviparus. Frequencies of the most common allele (p) and fitted Hardy-Weinberg proportions for eelpout, collected in Mariager Fjord in 1998 and 1977. N: number of individuals; na = not analysed

\begin{tabular}{|c|c|c|c|c|c|c|c|c|c|c|c|}
\hline \multirow{2}{*}{ Locus } & & \multicolumn{5}{|c|}{ Samples from 1998} & \multicolumn{5}{|c|}{ Samples from 1977} \\
\hline & & $98-2$ & $98-3$ & $98-4$ & $98-4 / 5$ & $98-5$ & $77-1$ & $77-2$ & $77-3$ & $77-4$ & $77-5$ \\
\hline AATIII & $\begin{array}{c}p \\
\mathrm{~F} \sqrt{ } \mathrm{N} \\
\mathrm{N}\end{array}$ & $\begin{array}{c}0.82 \\
-0.43 \\
45\end{array}$ & $\begin{array}{c}0.86 \\
-0.68 \\
18\end{array}$ & $\begin{array}{c}0.89 \\
2.90^{\mathrm{a}} \\
65\end{array}$ & $\begin{array}{l}0.86 \\
1.46 \\
104\end{array}$ & $\begin{array}{c}0.97 \\
-0.12 \\
17\end{array}$ & $\begin{array}{c}0.82 \\
-0.46 \\
240\end{array}$ & $\begin{array}{c}0.80 \\
-0.59 \\
300\end{array}$ & $\begin{array}{l}0.82 \\
0.28 \\
300\end{array}$ & $\begin{array}{l}0.82 \\
1.36 \\
300\end{array}$ & $\begin{array}{c}0.84 \\
-0.90 \\
270\end{array}$ \\
\hline$A D A$ & $\begin{array}{c}p \\
F \sqrt{ } \\
N\end{array}$ & $\begin{array}{c}0.70 \\
-1.40 \\
43\end{array}$ & $\begin{array}{c}0.75 \\
-0.16 \\
18\end{array}$ & $\begin{array}{c}0.79 \\
-0.01 \\
65\end{array}$ & $\begin{array}{l}0.86 \\
1.46 \\
104\end{array}$ & $\begin{array}{c}0.82 \\
0.79 \\
17\end{array}$ & $\begin{array}{c}0.77 \\
-0.22 \\
240\end{array}$ & $\begin{array}{c}0.75 \\
-0.61 \\
300\end{array}$ & $\begin{array}{l}0.82 \\
0.04 \\
300\end{array}$ & $\begin{array}{c}0.78 \\
-0.51 \\
300\end{array}$ & $\begin{array}{c}0.78 \\
-0.67 \\
270\end{array}$ \\
\hline ESTIII & $\begin{array}{c}p \\
F \sqrt{ } N \\
N\end{array}$ & $\begin{array}{c}0.60 \\
0.50 \\
45\end{array}$ & $\begin{array}{c}0.62 \\
-0.50 \\
17\end{array}$ & $\begin{array}{c}0.60 \\
-1.54 \\
63\end{array}$ & $\begin{array}{l}0.60 \\
0.18 \\
104\end{array}$ & $\begin{array}{c}0.59 \\
1.12 \\
17\end{array}$ & $\begin{array}{l}0.50 \\
1.03 \\
240\end{array}$ & $\begin{array}{l}0.45 \\
2.07^{a} \\
300\end{array}$ & $\begin{array}{l}0.49 \\
1.72 \\
300\end{array}$ & $\begin{array}{l}0.57 \\
1.51 \\
300\end{array}$ & $\begin{array}{c}0.59 \\
-1.52 \\
270\end{array}$ \\
\hline$H B I$ & $\begin{array}{c}p \\
\mathrm{~F} \sqrt{ } \mathrm{N} \\
\mathrm{N}\end{array}$ & $\begin{array}{l}\text { na } \\
\text { na } \\
\text { na }\end{array}$ & $\begin{array}{l}\text { na } \\
\text { na } \\
\text { na }\end{array}$ & $\begin{array}{l}\text { na } \\
\text { na } \\
\text { na }\end{array}$ & $\begin{array}{l}\text { na } \\
\text { na } \\
\text { na }\end{array}$ & $\begin{array}{l}\text { na } \\
\text { na } \\
\text { na }\end{array}$ & $\begin{array}{c}0.99 \\
-0.23 \\
240\end{array}$ & $\begin{array}{c}0.98 \\
-0.45 \\
298\end{array}$ & $\begin{array}{c}0.98 \\
-0.44 \\
300\end{array}$ & $\begin{array}{c}0.99 \\
-0.24 \\
294\end{array}$ & $\begin{array}{l}0.99 \\
5.34^{\mathrm{a}} \\
269\end{array}$ \\
\hline$M D H P I$ & $\begin{array}{c}p \\
\mathrm{~F} \sqrt{ } \\
\mathrm{N}\end{array}$ & $\begin{array}{c}0.50 \\
0.31 \\
42\end{array}$ & $\begin{array}{c}0.59 \\
1.12 \\
17\end{array}$ & $\begin{array}{c}0.63 \\
0.07 \\
65\end{array}$ & $\begin{array}{c}0.56 \\
-0.47 \\
95\end{array}$ & $\begin{array}{c}0.66 \\
1.23 \\
16\end{array}$ & $\begin{array}{c}0.58 \\
-2.30^{\mathrm{a}} \\
240\end{array}$ & $\begin{array}{l}0.60 \\
1.68 \\
300\end{array}$ & $\begin{array}{c}0.45 \\
-0.51 \\
300\end{array}$ & $\begin{array}{l}0.59 \\
0.61 \\
295\end{array}$ & $\begin{array}{l}0.55 \\
1.09 \\
270\end{array}$ \\
\hline MDHPII & $\begin{array}{c}p \\
F \sqrt{ } \\
N\end{array}$ & $\begin{array}{c}0.57 \\
0.94 \\
45\end{array}$ & $\begin{array}{c}0.44 \\
-0.30 \\
17\end{array}$ & $\begin{array}{c}0.74 \\
-1.35 \\
60\end{array}$ & $\begin{array}{l}0.63 \\
2.67^{\mathrm{a}} \\
104\end{array}$ & $\begin{array}{c}0.66 \\
1.23 \\
16\end{array}$ & $\begin{array}{l}\text { na } \\
\text { na } \\
\text { na }\end{array}$ & $\begin{array}{l}\text { na } \\
\text { na } \\
\text { na }\end{array}$ & $\begin{array}{l}\text { na } \\
\text { na } \\
\text { na }\end{array}$ & $\begin{array}{l}\text { na } \\
\text { na } \\
\text { na }\end{array}$ & $\begin{array}{l}\text { na } \\
\text { na } \\
\text { na }\end{array}$ \\
\hline PGMI & $\underset{\mathrm{F} \sqrt{ }}{p}$ & $\begin{array}{c}0.59 \\
-1.47 \\
44\end{array}$ & $\begin{array}{c}0.67 \\
-1.06 \\
18\end{array}$ & $\begin{array}{c}0.58 \\
-0.83 \\
65\end{array}$ & $\begin{array}{c}0.56 \\
-0.14 \\
104\end{array}$ & $\begin{array}{c}0.59 \\
-0.88 \\
17\end{array}$ & $\begin{array}{c}0.62 \\
-0.41 \\
240\end{array}$ & $\begin{array}{c}0.60 \\
0.14 \\
300\end{array}$ & $\begin{array}{c}0.59 \\
-0.58 \\
300\end{array}$ & $\begin{array}{c}0.58 \\
-0.93 \\
300\end{array}$ & $\begin{array}{l}0.60 \\
1.07 \\
270\end{array}$ \\
\hline PGMII & $\begin{array}{c}p_{\mathrm{F}} \sqrt{N}_{\mathrm{N}} \\
\mathrm{N}\end{array}$ & $\begin{array}{c}0.87 \\
-0.96 \\
43\end{array}$ & $\begin{array}{c}0.78 \\
-1.21 \\
18\end{array}$ & $\begin{array}{c}0.75 \\
0.00 \\
65\end{array}$ & $\begin{array}{l}0.80 \\
2.45^{\mathrm{a}} \\
104\end{array}$ & $\begin{array}{c}0.74 \\
3.50^{\mathrm{a}} \\
17\end{array}$ & $\begin{array}{l}0.79 \\
0.45 \\
240\end{array}$ & $\begin{array}{l}0.81 \\
0.36 \\
300\end{array}$ & $\begin{array}{l}0.79 \\
2.18^{\mathrm{a}} \\
300\end{array}$ & $\begin{array}{l}0.81 \\
0.97 \\
300\end{array}$ & $\begin{array}{c}0.79 \\
-1.61 \\
270\end{array}$ \\
\hline TPI & $\begin{array}{c}p_{\mathrm{F} \sqrt{N}} \\
\mathrm{~N}\end{array}$ & $\begin{array}{c}0.58 \\
0.60 \\
45\end{array}$ & $\begin{array}{c}0.44 \\
1.38 \\
18\end{array}$ & $\begin{array}{c}0.51 \\
2.11 \\
65\end{array}$ & $\begin{array}{c}0.52 \\
-0.41 \\
104\end{array}$ & $\begin{array}{c}0.62 \\
-1.53 \\
17\end{array}$ & $\begin{array}{l}\text { na } \\
\text { na } \\
\text { na }\end{array}$ & $\begin{array}{l}\text { na } \\
\text { na } \\
\text { na }\end{array}$ & $\begin{array}{l}\text { na } \\
\text { na } \\
\text { na }\end{array}$ & $\begin{array}{l}\text { na } \\
\text { na } \\
\text { na }\end{array}$ & $\begin{array}{l}\text { na } \\
\text { na } \\
\text { na }\end{array}$ \\
\hline
\end{tabular}

a Significant deviation from Hardy-Weinberg expectations

Given the fact that the samples from 1977 revealed heterogeneity, a grouping in accordance with the main geographic areas (inner and outer fjord) was performed for the 1977 samples. The group from the inner fjord consisted of Samples 77-1, 77-2 and 77-3, whereas the group from the outer part of the fjord encompassed Samples 77-4 and 77-5. The test for homogeneity within the inner group revealed homogeneity among the 3 samples $\left(\chi^{2}=19.54\right.$, df $=14, \mathrm{p}=$ $0.15)$. Homogeneity within the outer group was also found $\left(\chi^{2}=15.20\right.$, df $\left.=14, p=0.36\right)$.

\section{Ecological analysis}

Overall, the sex distribution deviated significantly from a 1:1 ratio at 4 out of 5 stations in 1998 and 3 out of 5 stations in 1915 and 1977, when tested by $\chi^{2}$-test and using Yate's correction for continuity. The sex distribution throughout the fjord did not show any clear pattern for the 3 sampling periods except that the samples from the inner part were quite similar for the years 1915 and 1977 (see Fig. 3). However, the 3 sampling periods, were not at the same time of year. The period in 1915 was July to September, in 1977 March to May, and in 1998 August to September (Table 1).

Tests for homogeneity of mean age among samples in 1998 showed significant deviation towards younger individuals at the mouth of the fjord (Welch's ANOVA $\left.F_{4,239}=4.41, \mathrm{p}=0.004\right)$, although $75 \%$ of the individuals were of the age $2+$. In contrast, the populations in the inner part of the fjord revealed significantly lower mean age in $1977\left(F_{4,1403}=129.83, \mathrm{p}<0.0001\right)$ than those from the mouth of the fjord. The average ages of the fish sampled in 1998 and 1977 are depicted in Fig. 4.

Lengths and weights were significantly greater for females than males among equal age classes in the Samples 98-2, 98-4 and 98-4/5 (paired $t$-test, $t=5.27$, $\mathrm{df}=10, \mathrm{p}<0.0005 ; t=3.65, \mathrm{df}=9, \mathrm{p}<0.0005 ; t=5.65$, $\mathrm{df}=25, \mathrm{p}<0.0005$, respectively). However, this was not the case for the Samples 98-3 and 98-5. The lengths of the most frequent age class (2+) were stratified by sex and tested for homogeneity between samples. Sample 98-5 was excluded with respect to males, as only 3 males occurred in this sample. No clear ten- 


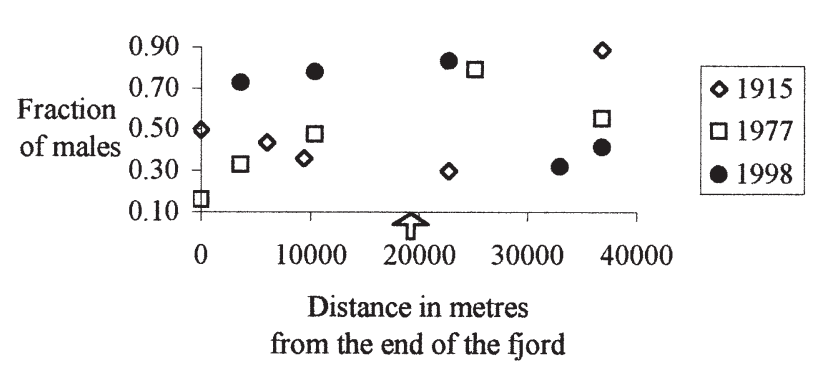

Fig. 3. Zoarces viviparus. Fraction of males in samples from 1915 (caught in July to September), 1977 (caught in March to May) and 1998 (caught in August to September) in Mariager Fjord. The arrow indicates the borderline between the deeper inner fjord and the shallower outer fjord

dency was seen, as males in Sample 98-3 were significantly longer than males in Sample 98-2 $\left(F_{3,85}=2.75\right.$, $\mathrm{p}=0.048$ ) whereas females in Sample 98-4 were significantly longer than females in Sample 98-2 and 98-4/5 $\left(F_{4,80}=4.06, \mathrm{p}=0.005\right)$. Females of year class $3+$ in Sample 77-1 were significantly longer than $3+$ females in any other sample $\left(F_{4,249}=27.35, \mathrm{p}=0.0001\right)$, whereas 3+ males only showed a significant difference between Samples 77-4 and 77-5 $\left(F_{4,172}=2.85, \mathrm{p}=\right.$ $0.025)$. The weight of the females was significantly different among samples $\left(F_{4,80}=8.49, \mathrm{p}=0.001\right)$, showing greater mean value in Sample 98-4 than in Samples 98-2, 98-4/5 and 98-5. However, 2+ males showed significantly heavier weight in Sample 98-3 than in Samples 98-2 and 98-4/5 $\left(F_{3,85}=3.31, \mathrm{p}=0.024\right)$.

The mean lengths of age classes in 1998 (sexes pooled) ranged from 16.4 (age class $1+$ ) to 29.1 (age class $4+$ ) as shown in Table 4. Analyses of co-variance on length-weight relationships between sexes in 1998 showed a significant difference between slopes in Sample 98-4/5, which represented the largest sample size of this study. Females showed steeper lengthweight relationships than males. Further analysis was not conducted due to the small sample size.

The condition factor (CF) of females was in all cases greater than for males. However, this difference was only statistically significant in Samples 98-4 $(t=4.07$, $\mathrm{df}=60, \mathrm{p}<0.0005)$ and 98-4/5 $(t=8.42, \mathrm{df}=93, \mathrm{p}<$ 0.0005). Consequently, each sample was divided according to sex. Females were, however, omitted from further analysis due to the fact that non-gravid females dominated the inner part of the fjord whereas only gravid females were present at the mouth of the fjord, represented by Samples 98-4, 98-4/5 and 98-5. $\mathrm{CF}$ of males differed significantly among samples $\left(F_{4,135}=10.34, \mathrm{p}<0.001\right)$, showing higher CF in Sample 98-4 than Samples 98-2, 98-4/5 and 98-5 (TukeyKramer, $\mathrm{p}<0.01, \mathrm{p}<0.0001$ and $\mathrm{p}<0.01$ respectively).

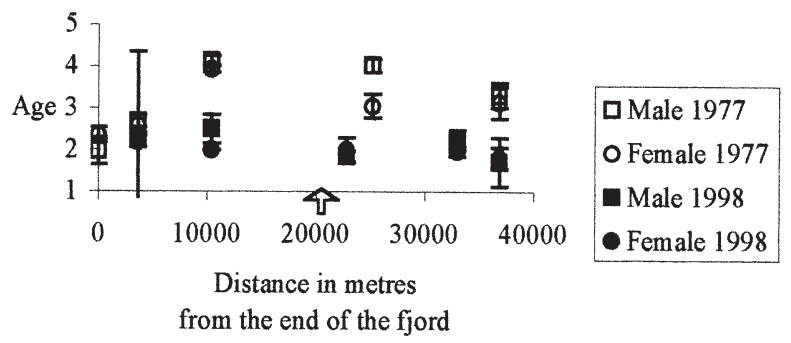

Fig. 4. Zoarces viviparus. Mean age by sex of eelpout collected in 1977 and 1998 (see months in Fig. 3) in Mariager Fjord. The arrow indicates the borderline between the deeper inner fjord and the shallower outer fjord

However, male length was negatively correlated with male CF (Pearson correlation, $\mathrm{r}^{2}=-0.19$, $\mathrm{p}=0.025$ ).

No significant difference in growth zone width of sagittae between sexes was found in growth zones 1 to 4. When sexes were pooled, only growth zone 4 showed a significant difference in width among the samples $\left(F_{4,232}=4.25, \mathrm{p}=0.002\right)$. The width was larger in 98-3 and 98-4 than in 98-5. Growth zones 6 and 7 revealed a significant difference between males and females (all $t>2.55$, all $\mathrm{p}<0.015$ ). The females were wider in these 2 zones than the males in Samples 98-2 and 98-4/5, and the same was found for zone 7 in Sample 98-4. When divided by sex, no significant difference among females over stations was found between widths for growth zones 5 to 7 . Male growth zone 7 was significantly larger in Sample 98-4 than in 98-2 $\left(F_{4,111}=5.13, \mathrm{p}<0.001\right)$. The outermost growth zone of $2+$ individuals was compared to the corresponding zones of $3+$ individuals (see 'Materials and methods').

Table 4. Zoarces viviparus. Mean lengths ( $\mathrm{L}$ in $\mathrm{cm}$ ) of age classes in the samples collected in Mariager Fjord 1998. $\mathrm{CN}$ : number of individuals; SD: standard deviation

\begin{tabular}{|c|c|c|c|c|c|}
\hline \multirow[b]{2}{*}{ Sample } & & \multicolumn{4}{|c|}{ Age classe } \\
\hline & & $1+$ & $2+$ & $3+$ & $4+$ \\
\hline \multirow[t]{3}{*}{$98-2$} & $\mathrm{~N}$ & 1 & 29 & 10 & \\
\hline & $\mathrm{L}$ & 16.60 & 20.09 & 22.27 & \\
\hline & $\mathrm{SD}$ & & 1.59 & 2.52 & \\
\hline \multirow[t]{3}{*}{$98-3$} & $\mathrm{~N}$ & & 12 & 5 & 1 \\
\hline & $\mathrm{L}$ & & 21.84 & 23.24 & 23.50 \\
\hline & $\mathrm{SD}$ & & 2.50 & 1.21 & \\
\hline \multirow[t]{3}{*}{$98-4$} & $\mathrm{~N}$ & 11 & 49 & 3 & \\
\hline & $\mathrm{L}$ & 16.56 & 20.76 & 24.60 & \\
\hline & $\mathrm{SD}$ & 1.97 & 2.15 & 0.12 & \\
\hline \multirow[t]{3}{*}{$98-4 / 5$} & $\mathrm{~N}$ & 11 & 76 & 11 & 3 \\
\hline & $\mathrm{L}$ & 17.05 & 21.85 & 23.56 & 31.00 \\
\hline & $\mathrm{SD}$ & 1.48 & 2.05 & 1.66 & 0.95 \\
\hline \multirow[t]{3}{*}{$98-5$} & $\mathrm{~N}$ & 5 & 11 & 1 & \\
\hline & $\mathrm{L}$ & 14.58 & 21.03 & 22.60 & \\
\hline & $\mathrm{SD}$ & 1.48 & 2.43 & & \\
\hline
\end{tabular}


Table 5. Zoarces viviparus. Catch per unit effort (CPUE) in the years 1998 and 1977

\begin{tabular}{|c|c|c|c|c|c|c|c|c|}
\hline \multirow[b]{2}{*}{ Sampling year } & \multicolumn{4}{|c|}{ Inner part of the fjord (Stns 1,2 and 3) } & \multicolumn{4}{|c|}{ Outer part of the fjord (Stns 4, 4/5 and 5) } \\
\hline & Catch days & No. of fish & No. of stations & CPUE & Catch days & No. of fish & No. of stations & CPUE \\
\hline 1998 & 310 & 57 & 7 & 0.18 & 444 & 329 & 36 & 0.74 \\
\hline $1977^{a}$ & 873 & 1344 & 19 & 1.54 & 122 & 582 & 6 & 4.77 \\
\hline
\end{tabular}

The width of the outermost zone in $2+$ fish in winter 1997 and summer 1998 was significantly smaller $(t=$ -5.45 , df $=204, \mathrm{p}<0.0005)$ than the width of the corresponding otolith region of $3+$ individuals assumed to be formed the year before the hypoxia event (i.e. winter 1996 and summer 1997).

Table 5 lists CPUE values for 1998 and values for the average of 3 earlier investigations. The fjord was divided into the inner part (Samples 98-1, 98-2 and 98-3) and the outer part (Samples 98-4, 98-4/5 and 98-5). A dramatic reduction in catches between the 1998 and earlier investigations can be seen. CPUE in the outer part of the fjord in 1998 was 6 times lower than in the investigations in the period 1969 to 1977, and 9 times lower in the inner part.

\section{DISCUSSION}

There are over 200 fish species found in northern European waters (North Sea Task Force 1993). However, the commercial fishery focuses on only about 10 species. Describing population dynamics in marine fishes requires data collected over long periods of time and, in most countries, the infrastructure required to collect and maintain such data sets is primarily found only in government fisheries laboratories. As the mandate for these laboratories concerns commercially important fish species, the availability of data that can be used to identify changes in the abundance or population dynamics of non-commercial fish species is limited. As the vast majority of marine fish species are not a direct target of the commercial fishery, little is known about the long-term variability in population characteristics for most marine fish species in northern Europe.

There has, however, been increasing interest in recent years in identifying changes in marine ecosystems that might be caused by human impacts such as eutrophication (e.g. Jørgensen \& Richardson 1996) and fisheries (e.g. North Sea Task Force 1993, Hall 1999). The need for better understanding of the long-term changes in the abundance and population characteristics of commercially unimportant fish species has been identified by these efforts. The ratification of the Biodiversity Convention (see http://www.biodiv.org/) by most countries has further accentuated the need to develop an understanding of the abundance and population status of non-commercial fish species.

It is obviously not possible to collect long-term data sets retrospectively. Therefore, an understanding of the historical development of population characteristics for fish species where catch or assessment data have not been routinely collected will only be possible in a limited number of cases. One approach to studying population dynamics in such species is to replicate earlier studies described in the scientific literature on specific species. We have applied this approach to the study of eelpout in Mariager Fjord.

Earlier studies in this fjord had suggested the existence of 2 populations in the fjord (Schmidt 1917a,b, Christiansen et al. 1981, 1988). To ensure that the data we collected in 1998 and the earlier data were statistically analysed in the same manner, we re-examined the data presented by Christiansen et al. (1988). This re-examination of the data confirmed the earlier conclusion of 2 sub-populations of eelpout in Mariager Fjord at the time of the 1977 sampling (Tables 2 \& 3, Fig. 2.). An analysis of our data from 1998 does not, however, suggest the existence of 2 sub-populations in this later sampling year when considering either morphological traits or isozymes. This tendency is obvious despite the fact that the small sample sizes reduce the power of the statistical tests. Homogeneity tests among samples, including all loci in 1998, revealed a low p-value, due to a few significant pair-wise comparisons among samples (ADA and MDHPII). However, this was not found for EST in 1998. In contrast, this locus was the only one revealing significant difference among the samples for 5 out of 10 possible combinations in 1977.

The eelpout population found in Mariager Fjord in 1998 has similar morphological and genetic characteristics as fish found in the outer fjord in the earlier studies. This suggests that the inner fjord population has been severely reduced (or eliminated) and that the outer fjord population has extended its distribution into the inner fjord. We cannot identify the cause(s) of such a reduction in the inner fjord population. However, we note that eutrophication of this fjord has occurred in the latter part of the 20th century (Andersen et al. 
1998). Furthermore, the fjord suffered a serious oxygen depletion event with $17 \mathrm{~d}$ of 0 to $2 \%$ oxygen tension in the inner part of the fjord in late August 1997 (Andersen et al. 1998). This event resulted in an extensive fish kill especially in the inner part of the fjord (Andersen et al. 1998).

Eelpout are capable of surviving moderate hypoxia for longer periods by reducing oxygen consumption markedly (Fischer et al. 1992) and may even benefit from such moderate conditions in terms of easily available food items. Fischer et al. (1990), studied the behavioural response of eelpout under oxygen depletion and found that, in addition to reduced respiration, the fish exhibited reduced locomotory activity. No escape behaviour was observed and the fish could survive for $60 \mathrm{~min}$ in oxygen-free water. The lack of escape behaviour might increase the possibility for fish kills under extended periods of hypoxia/anoxia. A population in the inner fjord that did not exhibit escape behaviour to periods of oxygen depletion would be particularly vulnerable during an anoxia event such as the one occurring in 1997. The growth of $3+$ individuals during winter 1996 and summer 1997 was significantly greater than in the corresponding growth period (i.e. winter 1997 and summer 1998) for 2+ individuals that may have experienced sublethal conditions due to the hypoxia event. This comparison was, however, between different individuals and in different years, and may not be a result of the hypoxia event. Unfortunately, it was not possible to compare only summer growth between 1997 and 1998.

No clear pattern was observed with respect to comparison of length, weight and CF among samples in 1998. Samples were divided according to age and sex before analysis, which for some samples resulted in very small sample sizes. A greater CF might be expected at the mouth of the fjord, due to the presence of eel-grass spots and sandy sediment. Male CF from samples at the mouth of the fjord showed significantly higher values than Sample 98-2 from the inner part of the fjord. Additionally, 2+ females were longer and heavier in samples from the mouth of the fjord. Due to the event of severe hypoxia in late August 1997, the mussel banks, which covered the bottom of the end of the fjord, died. New settlers might more likely settle here, where attachment had previously been established, than at the sandy mouth of the fjord (Sørensen \& Wiggers 1997). Food might therefore be abundant at the end of the fjord, as new settlers could not have reached the stage of size refugium with respect to eelpout. Accordingly, 2+ males were significantly heavier in 1 sample at the end of the fjord (Sample 98-3) than in samples at the mouth of the fjord (Sample 98-4/5 and 98-5). No clear tendencies with respect to the growth of eelpout in the fjord could be deduced.
Population characteristics determined for fish collected in 1915 and fish collected in 1977 lead to the common conclusion that there were 2 populations of eelpout in Mariager Fjord. This suggests that the presence of 2 populations may have been a stable feature of the fjord from the early 1900s at least until the late 1970s. That the conclusion cannot be confirmed from samples taken in 1998 suggests that the population structure of this species may have changed dramatically in the fjord during the latter part of the 20th century.

A comparison of catch data from the 1977 and 1998 studies (Table 5) indicates that the abundance of eelpout in the fjord has also declined dramatically during the same period. The recorded age distribution of fish in the fjord was different in the late 1990s compared to that observed in the 1970s (Fig. 4). In 1998, the population was dominated by younger fish than in 1977. Differences in the age distribution of fish populations in 2 different sampling years can reflect the influence of unusually strong or weak year classes. However, they may also reflect differences in size specific mortality. One source of mortality for eelpout is predation by cormorants Phalacrócorax cárbo (Hald Mortensen 1995) and there has been a dramatic increase in cormorant abundance in the region around Mariager Fjord between the 1970s and 1990s (see http://www.dmu. $\mathrm{dk} /$ news/natur and Eskildsen 2000). It is not known whether or not the effect of the increased cormorant predation on eelpout is of quantitative importance for this fish population in Mariager Fjord. We note, however, that both eutrophication and change in abundance of cormorants represent 2 obvious changes in the living conditions for eelpout in this fjord, which have occurred in the period between the 1977 sampling, when 2 populations of eelpout were identified, and 1998, when only 1 population could be identified.

The fact that Schmidt (1917a) was able to identify 'race differentiation' in eelpout over the small geographic area of the Mariager Fjord led him to suggest that the fish must be relatively stationary in their distribution. This assumption has prevailed in the general literature ever since (e.g. Christiansen et al. 1973, Ojaveer \& Lankov 1997). The fact that the eelpout found in the inner Mariager Fjord in 1998 had similar morphological and genetic traits as those previously associated with the outer fjord did not support the assumption of relatively stationary populations. Moreover, a small number of 1 yr olds found in the outer part of the fjord in 1998 showed morphological traits similar to these found in coastal populations by Smith (1917a), which might indicate some migrating activity. Additionally, a comparison of the relative distributions of males and females during the 1917, 1977 and 1998 studies suggested that there must be some migration of 
eelpout in the fjord. The sex ratios observed deviated significantly from 1:1, as shown in Fig. 3. However, neither obvious seasonal pattern nor evidence for depth migration, as found in other investigations (Jansson et al. 1985, Ojaveer 1997), was observed. The sex ratio in the spawning area in Kaloe Cove near Aarhus deviated significantly from 1:1 over $6 \mathrm{yr}$, with an excess of females in all years (Christiansen et al. 1977). The fishing period was November to December and the result could be explained by selectivity of the fishing gear for the gravid females.

In a survey carried out in Danish waters, an excess of females was found at 6 out of 15 stations sampled in the period October to December (Hjorth \& Simonsen 1975). In the period February to May, 4 out of 10 stations had an excess of males. One station that was studied both in March and November had an excess of females on both occasions. Most likely, the sex ratio is close to a 1:1 ratio but it may also be dependent on the time of the year and the location of sampling. This variation in sex ratio indicates that at least some migration must take place despite the sedentary nature of the eelpout.

In our attempt to examine population dynamics for the eelpout in this Danish fjord, we were fortunate to find data pertaining to the biology and distribution of this species in the fjord for 2 different periods in the 1900s. Modern genetic methods (e.g. microsatellites) allow a much more detailed description of population structure than the one we present here. However, by replicating the methods used in earlier studies, we have been able to compare the population structure of a non-commercial coastal marine fish species at 3 different points in time during a $90 \mathrm{yr}$ period. The picture that emerges suggests major changes in the population dynamics of eelpout in Mariager Fjord during the last 20 to 30 yr. The causes of the observed changes in population structure cannot yet be identified. Nevertheless, we believe that studies such as this are useful in identifying possible changes in population and ecosystem structure in coastal marine waters.

Acknowledgements. We thank Verner Damm, Villy Brorstrup, Finn Frandsen, Finn Christensen and Allan Eriksen for providing the fish, and the Danish Institute for Fisheries Research for allowing us to use their traps for the fishery. Freddy Bugge Christiansen gave us permission to use the data from 1977. In addition, we thank Jørgen Nielsen and Peter Rask Møller for allowing us to use the X-ray equipment, and Ole Bagge for help with the estimation of CPUE.

\section{LITERATURE CITED}

Andersen F, Andersen JM, Brock K, Fallesen G and 6 others (1998) Mariager Fjord; history and status 1997. Århus Amt \& Nordjyllands Amt, Århus (in Danish)
Christiansen FB, Frydenberg O (1974) Geographical patterns of four polymorphisms in Zoarces viviparus as evidence of selection. Genetics 77:765-770

Christiansen FB, Frydenberg O, Simonsen V (1973) Genetics of Zoarces populations. IV. Selection component analysis of an esterase polymorphism using population samples including mother-offspring combinations. Hereditas 73:291-304

Christiansen FB, Frydenberg O, Hjorth JP, Simonsen V (1976) Genetics of Zoarces populations. IX. Geographic variation at the three phosphoglucomutase loci. Hereditas 83: 245-256

Christiansen FB, Frydenberg O, Simonsen V (1977) Genetics of Zoarces populations. X. Selection component analysis of the ESTIII polymorphism using samples of successive cohorts. Hereditas 87:129-150

Christiansen FB, Nielsen BV, Simonsen V (1981) Genetical and morphological variation in the eelpout Zoarces viviparus. Cand J Genet Cytol 23:163-172

Christiansen FB, Frydenberg O, Simonsen V (1984) Genetics of Zoarces populations. XII. Variations at the polymorphic loci PgmI, PgmII, HbI and EstIII in fjords. Hereditas 101: $37-48$

Christiansen FB, Nielsen VH, Simonsen V (1988) Genetics of Zoarces populations. XV. Genetic and morphological variation in Mariager Fjord. Hereditas 109:99-112

Eskildsen J (2000) Cormorants 2000. Danmark. National Environmental Research Institute Monitoring Report, Kaloe 136 (in Danish)

Fischer P, Kils U, Waller U (1990) In situ investigations on the behaviour and respiration of the three-spined stickleback (Gasterosteus aculeatus L.) and the eelpout (Zoarces viviparus L.) ICES C.M./F:23

Fischer P, Rademacher K, Kils U (1992) In situ investigations on the respiration and behaviour of the eelpout (Zoarces viviparus L.) under short-term hypoxia. Mar Ecol Prog Ser 88:181-184

Fowler J, Cohen L, Jarvis P (1998) Practical statistics for field biology. 1st edn, John Wiley \& Sons, Chichester

Frydenberg O, Simonsen V (1973) Genetics of Zoarces populations. V. Amount of protein polymorphism and degree of genic heterozygosity. Hereditas 75:221-232

Goudet J (1995) Fstat version 1.2: A computer program to calculate F statistics. J Hered 86:485-486

Hald Mortensen P (1995) Danish cormorants' choice of food: 1992-1994 (in Danish). Environmental and Energy Ministery, National Forest and Nature Agency, Copenhagen

Hall SJ (1999) The effects of fishing on marine ecosystems and communities. Blackwell Science, Oxford

Hjorth JP (1971) Genetics of Zoarces populations. I. Three loci determining the phosphoglucomutase isoenzymes in brain tissue. Hereditas 69:233-242

Hjorth JP, Simonsen V (1975) Genetics of Zoarces populations. VIII. Geographic variation common to the polymorphic loci $H b I$ and EstIII. Hereditas 81:173-184

Jansson BO, Aneer G, Nellbring S (1985) Spatial and temporal distribution of the demersal fish fauna in a Baltic archipelago as estimated by SCUBA census. Mar Ecol Prog Ser 23:31-43

Jørgensen BB, Richardson K (1996) (eds) Eutrophication in coastal marine ecosystems. Coastal and estuarine studies series 52, American Geophysical Union, Washington, DC

King M (1995) Fisheries biology, assessment and management. Blackwell Science, Oxford

Manchenko GP (1994) Handbook of detection of enzymes on electrophoretic gels. CRC Press, Boca Raton

North Sea Task Force (1993) North Sea quality status report. Oslo and Paris commissions, London 
Ojaveer H (1997) Composition and dynamics of fish stocks in the Gulf of Riga ecosystem. Dissertationes Biologicae Universitatis Tartuensis 31, Tartu University Press, Tallin

Ojaveer H, Lankov A (1997) Adaptation of eelpout, Zoarces viviparus (L.), to spatially changing environment on the coastal slope of the Gulf of Riga (Baltic Sea). ICES CM7EE:03

Raymond M, Rousset F (1995) GENEPOP (version 1.2): Population genetics software for exact tests and ecumenicism. J Hered 86:248-249

Rice WR (1989) Analysing tables of statistical tests. Evolution 43:223-225

Schmidt J (1917a) Racial investigations I. Zoarces viviparus L. and local races of the same. C R Trav Lab Carlsberg 13 (3): 277-397

Schmidt J (1917b) Racial investigations II. Constancy investigations continued. C R Trav Lab Carlsberg 14 (1):1-19

Schmidt J (1921) Racial investigations VII. Annual fluctuations of racial characters in Zoarces viviparus L. C R Trav Lab Carlsberg 14 (15):1-24

Siegel S, Castellan NJ Jr (1988) Nonparametric statistics for the behavioral sciences. 2nd edn, McGraw-Hill, New York

Editorial responsibility: Otto Kinne (Editor), Oldendorf/Luhe, Germany
Simonsen V, Christiansen FB (1981) Genetics of Zoarces populations. XI: Inheritance of electrophoretic variants of the enzyme adenosine deaminase. Hereditas 95:289-294

Simonsen V, Christiansen FB (1984) Genetics of Zoarces populations. XIII. Three loci determining isoenzymes of glutamic-oxaloacetic transaminase. Hereditas 101:129-136

Simonsen V, Frydenberg O (1972) Genetics of Zoarces populations II. Three loci determining esterase isozymes in eye and brain tissue. Hereditas 70:235-242

Sokal RR, Rohlf FJ (1995) Biometry. The principles and practice of statistics in biological research. 3rd edn. WH Freeman, New York

Svedäng H, Ojaveer H, Urtans E (1997) Interpretation of the otolith structures in viviparous blenny Zoarces viviparus. J Appl Ichthyol 13:137-142

Sørensen HM, Wiggers L (1997). Notat. Iltsvind i Mariager Fjord. Status. Århus og Nordjyllands Amt, in Århus (in Danish)

Weir BS, Cockerham CC (1984) Estimating F-statistics for the analysis of population structure. Evolution 38:1358-1370

Zar JH (1996) Biostatistical analysis. 3rd edn. Prentice-Hall, Upper Saddle River, NJ

Submitted: February 15, 2001; Accepted: June 21, 2001 Proofs received from author(s): February 1, 2002 